\title{
Persepsi Peserta Didik Terhadap Pembelajaran Daring Pjok
}

\author{
Kadek Santhi Pratiwi ${ }^{*}$, I Gusti Lanang Agung Parwata ${ }^{2}$, Kadek Yogi Parta \\ Lesmana $^{3}$
}

1,2,3 Jurusan Pendidikan Olahraga, Universitas Pendidikan Ganesha Singaraja, Indonesia

\section{ART ICLE INFO}

\section{Article history:}

Received June 04, 2021

Revised June 09, 2021

Accepted July 07, 2021

Available online July 25, 2021

Kata Kunci:

Persepsi, Pembelajaran Daring PJOK

Keywords:

Perception, Online Learning, PJOK

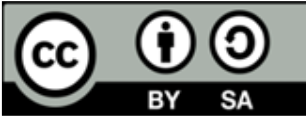

This is an open access article under the CC BY-SA license.

Copyright (ㅇ) 2021 by Author. Published by Universitas Pendidikan Ganesha.

\begin{abstract}
A B S T R A K
Mewabahnya virus corona, mengakibatkan seluruh pembelajaran dilakukan secara daring (online). Pembelajaran daring membawa dampak terhadap proses pembelajaran yaitu selama proses pembelajaran daring siswa bosan untuk belajar karena kurangnya interkasi antara siswa dan guru. Tidak hanya itu pembelajarn daring juga merupakan tantangan baru untuk guru dalam proses mengajarnya. Penelitian ini bertujuan untuk mengetahui persepsi peserta didik kelas terhadap pembelajaran daring PJOK. Desain penelitian menggunakan desain penelitian kuantitatif dengan pendekatan eksploratif. Subjek penelitian ini adalahpeserta didik yang berjumlah 184 siswa. Besarnya sampel dalam penelitian ini ditentukan dengan rumus Slovin dengan pertimbangan bahwa populasi relatif homogen/seragam sehingga tidak terlalu diperlukan untuk distratifikasi. Teknik pengumpulan data yang digunakan dalam penelitian ini adalah teknik kuesioner. Setelah data terkumpul kemudia dianalisis menggunakan metode analisa statistik desktiptif. Hasil penelitian ini menunjukkan bahwa: (1) sebagian besar peserta didik $(41,85 \%)$ memiliki persepsi yang baik terhadap pembelajaran daring PJOK dan (2) skor rata-rata persepsi peserta didik terhadap pembelajaran daring PJOK sebesar 89,91 berada pada kategori baik. Jadi dapat disimpulkan bahwa peserta didik memiliki persepsi yang baik terhadap pembelajaran daring PJOK.
\end{abstract}

\begin{abstract}
A B S T R A K
The outbreak of the corona virus has resulted in all learning being carried out online. Online learning has an impact on the learning process, namely during the online learning process students are bored to learn because of the lack of interaction between students and teachers. Not only that, online learning is also a new challenge for teachers in their teaching process. This study aims to determine the perception of class students towards PJOK online learning. The research design uses a quantitative research design with an exploratory approach. The subjects of this study were 184 students. The sample size in this study was determined by the Slovin formula with the consideration that the population was relatively homogeneous/uniform so it was not necessary to stratify. The data collection technique used in this research is a questionnaire technique. After the data is collected, it is analyzed using descriptive statistical analysis methods. The results of this study indicate that: (1) most students (41.85\%) have a good perception of PJOK online learning and (2) the average score of students' perceptions of PJOK online learning is 89.91 which is in the good category. . So it can be concluded that students have a good perception of PJOK online learning.
\end{abstract}

\section{PENDAHULUAN}

Indonesia saat ini sedang mengalami wabah virus corona. Virus Corona ini diberi nama corona virus disease 2019 (COVID-19) yang disebabkan oleh Severe Acute Respiratory Syndrome Coronavirus-2 (SARS-CoV-2) yaitu virus yang menyerang sistem pernapasan (R. S. Putri \& Purwanto, 2020; Susilo et al., 2020). Pandemi COVID-19 memberikan dampak yang signifkan di semua bidang, khususnya pendidikan (Prayitno \& Mardianto, 2020). Salah satu kebijakan yang dilakukan pemerintah guna memutus rantai 
penyebaran virus corona dalah dengan menerapkan gerakan social distancing (Buana, 2020; WilderSmith \& Freedman, 2020). Pemerintah menganjurkan menjaga jarak aman dengan manusia lainnya minimal 2 meter, tidak melakukan kontak langsung dengan orang lain, dan menghindari kerumunan massal (Firman, F., \& Rahayu, 2020). Sedangkan dalam dunia pendidikan Menteri Nadiem Anwar Makarim menerbitkan Surat Edaran Nomor 3 Tahun 2020 pada Satuan Pendidikan dan Nomor 36962/MPK.A/HK/2020 tentang Pelaksanaan Pendidikan dalam Masa Darurat Coronavirus Disease (COVID-19) maka dari itu kegiatan belajar dilakukan secara daring (online) dalam rangka pencegahan penyebaran coronavirus disease (COVID-19) (Jamilah, 2020; Napitupulu, 2020; Prayitno \& Mardianto, 2020).

Pembelajaran daring, online, atau pembelajaran jarak jauh bertujuan untuk memenuhi standar pendidikan dengan pemanfaatan teknologi informasi dengan menggunakan perangkat komputer atau gadget yang saling terhubung dengan siswa dan guru maupun mahasiswa dengan dosen (Mustofa, Chodzirin, \& Sayekti, 2019; Pakpahan \& Fitriani, 2020). Pembelajaran daring adalah pembelajaran yang dilakukan tanpa melakukan tatap muka, tetapi menggunakan jaringan internet dengan media platform yang telah tersedia (Imania \& Bariah, 2019). Dengan pembelajaran daring peserta didik memiliki keleluasaan dalam waktu belajar, dapat belajar kapanpun dan dimanapun. Siswa dapat berinteraksi dengan guru menggunakan beberapa aplikasi seperti classroom, video conference, telepon atau live chat, zoom maupun melalui whatsapp group. Pembelajaran daring saat ini merupakan solusi yang dinilai efektif guna mengatasi permasalahan di bidang pendidikan akibat pandemic covid-19 (A. Putri \& Suparmi, 2020).

PJOK adalah satu satu mata pelajaran yang proses pembelajarannya dilaksanakan secara daring. Pendidikan jasmani olahraga dan kesehatan (PJOK) merupakan salah satu bagian dari mata pelajaran yang diberikan di sekolah menengah pertama (SMP). Mata pelajaran PJOK untuk meningkatkan sumber daya manusia terutama dalam bidang fisik, pembinaan hidup sehat jasmani dan rohani yang dalam seharihari menuju sehat seutuhnya (Juniarta \& Winarno, 2016). Pendidikan Jasmani Olahraga dan Kesehatan merupakan pendidikan yang melibatkan aktivitas gerak secara sadar guna mencapai tujuan pembelajaran (Anwar \& Hartoto, 2019; Hendri \& Azis, 2020; Rochman, Indahwati, \& Priambodo, 2020). Oleh karenanya terdapat kendala yang dialami oleh siswa terutama dalam mata pelajaran pendidikan jasmani kesehatan dan olahraga karena pada dasarnya didominasi oleh aspek psikomotorik (keterampilan fisik). Di dalam praktikumnya siswa terbatas oleh ruang gerak dikarenakan tempat yang kurang mendukung, selain itu daya serap siswa dalam mempelajari materi tidak semudah dengan apa yang dilihat atau dicontohkan oleh tenaga pendidik. Bagi tenaga pengajar, pembelajaran daring hanya efektif untuk penugasan, sedangkan untuk membuat peserta didik memahami materi pembelajaran secara daring dinilai sulit (Maulana \& Iswari, 2020). Selain itu, kemampuan teknologi dan ekonomi setiap peserta didik berbedabeda. Tidak semua peserta didik memiliki fasilitas yang menunjang kegiatan pembelajaran daring. Koneksi internet yang tidak memadai, perangkat yang tidak mendukung, dan kuota internet yang mahal menjadi penghambat pembelajaran daring (Henik, I, Indarto A.S, 2014; Jariyah \& Tyastirin, 2020; Margiyanti, Handayani, \& Roza, 2021; Ni'mah, 2016). Kendala lain adalah kurangnya kemampuan guru dalam memahami konsep seperti apa pembelajaran daring, serta guru kurang update mengenai pembelajaran daring ini dengan menggunakan platform-platform yang telah tersedia (Pertiwi \& Sutama, 2020). Pembelajaran daring yang dilakukan selama pandemi covid-19 ini juga menimbulkan berbagai persepsi.

Persepsi adalah proses pengamatan seseorang yang berasal dari komponen kognisi. Persepsi ini dipengaruhi oleh faktor-faktor pengalaman, proses belajar dan pengetahuan (Irawati \& Santaria, 2020). Persepsi merupakan kecakapan untuk melihat, memahami, kemudian menafsirkan suatu stimulus sehingga merupakan sesuatu yang berarti dan menghasilkan penafsiran (Adila \& Harisah, 2020). Persepsi dari siswa mencerminkan sikap atau perilaku yang mereka lakukan setelah mengikuti proses pembelajaran daring mata pelajaran PJOK. Sikap dan perilaku mereka berasal dari pengamatan selama mengikuti proses pembelajaran daring. Hasil pengamatan tersebut akan memunculkan sebuah persepsi dimana persepsi tersebut bisa ke arah positif atau ke arah negatif tergantung dari pengamatan setiap individunya (Rahman, Gani, \& Achmad, 2020). Saat pembelajaran daring berlangsung beberapa siswa beranggapan bahwa pembelajaran daring tidak menyenangkan dan sangat membosankan karena hanya mendengarkan dan melihat gerakan melalui video atau gerakan langsung dari guru. Anggapan tersebut berbeda dari yang diharapkan oleh guru yang mengupayakan pembelajaran menjadi semenarik mungkin agar siswa merasa senang, nyaman dan tidak merasa terbebani untuk mengikuti pembelajaran daring.

Persepi yang baik terhadap pembelajaran PJOK diharapkan dapat memberi nilai lebih bagi siswa dalam rangka meningkatkan aktivitas berlajarnya disekolah. Persepsi yang sempit dan keliru terhadap pendidikan jasmani akan mengakibatkan nilai-nilai luhur dan tujuan pendidikan yang terkandung didalamnya tidak akan tercapai. Orientasi pembelajaran harus disesuaikan sehingga menarik dan menyenangkan, sasaran pembelajaran bukan hanya ditujukan untuk mengembangkan keterampilan 
olahraga tetapi perkembangan pribadi anak seutuhnya. Konsep dasar pendidikan dan model pengajaran PJOK yang efektif perlu dipahami bagi individu (siswa) yang hendak mengajar PJOK. Individu (siswa) yang memiliki persepsi positif atau baik tentang suatu obyek (mata pelajaran penjas) maka ia akan memiliki motivasi belajar yang positif atau baik, akan tetapi apabila individu memiliki persepsi yang negatif atau buruk tentang suatu obyek makan ia akan memiliki motivasi yang sangat buruk. Ini membuktikan bahwa persepsi siswa terhadap mata pelajaran penjas sangat berpengaruh terhadap keberhasilan pembelajaran penjas itu sendiri.

Terdapat beberapa hasil penelitian terdahulu yang relevan dengan penelitian ini. Pertama, Penelitian Hadi (2020) menunjukkan bahwa mahasiswa lebih menyukai pembelajaran luring daripada daring. Pembelajaran daring menyulitkan bagi mahasiswa karena kurangnya bahan belajar dan kurangnya akses internet. Kedua, penelitian Sari and Nazirun (2016) menunjukkan bahwa persepsi siswa terhadap proses pembelajaran pendidikan jasmani olahraga dan kesehatan adalah masuk kedalam kategori baik. Ketiga, penelitian yang dilakukan oleh Zuriati and Briando (2020) menunjukkan bahwa dalam pelaksanaan pembelajaran jarak jauh terdapat beberapa dimensi yang harus menjadi perhatian utama. Dimensi tersebut antara lain: Materi atau mode ajar, interaksi siswa, dan suasana belajar. Oleh karena itu, penelitian ini memiliki fokus pada persepsi siswa terhadap dimensi pelaksanaan pembelajaran online. Berdasarkan hasil penelitian yang relevan diatas dapat diketahui bahwa persepsi siswa terhadap pembelajaran daring selama pandemi cukup bervariasi yakni ada yang suka dan ada yang tidak, sehingga menarik untuk diteliti. Adapun perbedaan penelitian ini dengan penelitian sebelumnya yakni pada penelitian ini peneliti melakukan analisis mengenai persepsi peserta didik SMP selama mengikuti proses pembelajaran secara daring, apakah siswa senang saat belajar daring atau malah bosan karena merasa bosan serta kurangnya inetaksi saat belajar. Dengan tujuan untuk untuk mengetahui persepsi peserta didik kelas terhadap pembelajaran daring PJOK.

\section{METODE}

Jenis penelitian yang dilakukan termasuk ke dalam penelitian deskriptif eksploratif, bertujuan untuk menggambarkan keadaan sebenarnya dengan menggali sebab-sebab terjadinya persepsi siswa kelas VIII terhadap pembelajaran daring pendidikan jasmani olahraga dan kesehatan di SMP Negeri 1 Singaraja. Penelitian ini dilaksanakan pada SMP Negeri 1 Singaraja. Dalam penelitian ini ditetapkan persepsi peserta didik terhadap pembelajaran daring PJOK sebagai variabel penelitian. Subjek penelitian ini adalah pada peserta didik kelas VIII SMP Negeri 1 Singaraja tahun pelajaran 2020/2021. Objek penelitian ini adalah persepsi peserta didik terhadap pembelajaran daring PJOK. Populasi penelitian ini adalah seluruh peserta didik kelas VIII SMP Negeri 1 Singaraja tahun pelajaran 2020/2021 sebanyak 340 orang, yang masing-masing terdistribusi dalam 10 kelas. Besarnya sampel dalam penelitian ini ditentukan dengan rumus Slovin dengan pertimbangan bahwa populasi relatif homogen/seragam sehingga tidak terlalu diperlukan untuk distratifikasi. Hasil perhitungan dengan rumus Slovin menunjukkan jumlah sampel dalam penelitian ini adalah 184 orang. Alasan menggunakan rumus Slovin adalah untuk mendapat sampel yang representative dan lebih pasti atau mendekati populasi yang ada. Sumber data dalam penelitian ini meliputi data primer. Data primer, yaitu data yang bersumber dari sumber pertama. Data primer tersebut berupa data tentang persepsi peserta didik terhadap pembelajaran daring PJOK. Data persepsi peserta didik terhadap pembelajaran daring PJOK bersumber dari jawaban kuesioner yang dijawab langsung oleh responden.

Teknik pengumpulan data yang digunakan dalam penelitian ini adalah teknik kuesioner. Teknik ini dilakukan dengan memberikan daftar pertanyaan kepada responden untuk menjawab terutama yang berhubungan dengan variabel-variabel yang akan diteliti, yaitu variabel persepsi peserta didik terhadap pembelajaran daring PJOK. Dalam pengukuran variabel menggunakan metode kuesioner, variabel persepsi peserta didik terhadap pembelajaran daring PJOK dijabarkan ke dalam indikator-indikator yang akan menjadi pertanyaan kepada responden dalam penelitian ini. Untuk menentukan kelayakan setiap butir pertanyaan digunakan dalam penelitian, maka dilakukan uji validitas untuk mengukur kelayakan dan keandalan setiap butir pertanyaan di dalam kuesioner. Uji validitas bertujuan untuk menentukan apakah alat ukur yang akan digunakan dalam mengukur sebuah variabel sudah tepat digunakan atau belum. Dalam penelitian ini digunakan uji validitas isi karena alat ukur yang digunakan untuk mengukur persepsi peserta didik terhadap pembelajaran daring PJOK ini berupa kuesioner. Untuk menghitung validitas isi kuesioner maka digunakan rumus uji validitas isi dari Gregory. Untuk dapat mengolah data yang dikumpulkan, maka sistem penskoran kuesioner yang digunakan adalah skala likert. Skala pengukuran yang digunakan dalam pengukuran persepsi siswa terhadap pembelajaran daring pendidikan jasmani olahraga dan kesehatan di SMP Negeri 1 Singaraja pada penelitian ini adalah dengan menggunakan skala likert poin 1-5. Metode analisis data yang dilakukan pada penelitian ini adalah 
metode analisa statistik desktiptif, dimana dari nilai total jawaban butir pertanyaan akan diambil nilai rata-ratanya untuk kemudia nilai tersebut dipetakan ke dalam rentang skala statistik desktiptif, untuk kemudian disimpulkan dari hasil nilai rata-rata tersebut.

\section{HASIL DAN PEMBAHASAN}

Penelitian ini dilaksanakan pada kelas VIII di SMP Negeri 1 Singaraja. Tujuan penelitian ini adalah untuk mengetahui persepsi peserta didik kelas VIII terhadap pembelajaran daring PJOK. Dengan demikian, data penelitian ini berupa skor persepsi peserta didik terhadap pembelajaran daring PJOK, yang diperoleh dari kuesioner online google form pada kelas VIII di SMP Negeri 1 Singaraja. Data skor persepsi peserta didik terhadap pembelajaran daring PJOK tersebut dianalisis secara deskriptif menggunakan SPSS 24.0 for Windows. Skor persepsi peserta didik terhadap pembelajaran daring PJOK mencakup aspek ketertarikan materi ajar, kemudahan materi ajar, penilaian lingkungan, penilaian suasana, interaksi siswa, dan manfaat. Adapun data skor persepsi peserta didik terhadap pembelajaran daring PJOK dapat dilihat pada Tabel 1.

Tabel 1. Deskripsi Data Skor Persepsi Peserta Didik Terhadap Pembelajaran Daring PJOK

\begin{tabular}{cc}
\hline Deskripsi & Skor Persepsi Peserta Didik \\
\hline Banyak Siswa & 184 Orang \\
Rata-rata & 89,91 \\
Standar deviasi & 12,84 \\
Nilai minimum & 61 \\
Nilai maksimum & 120 \\
\hline
\end{tabular}

Berdasarkan Tabel 1 tampak bahwa data skor persepsi peserta didik terhadap pembelajaran daring PJOK pada kelas VIII di SMP Negeri 1 Singaraja mempunyai skor rata-rata sebesar 89,91 dengan nilai standar deviasi sebesar 12,84, nilai minimum 61, dan nilai maksimum 120. Hasil ini mengindikasikan bahwa secara deskriptif diperoleh standar deviasi lebih kecil dari skor rata-rata menunjukkan bahwa data skor persepsi peserta didik terhadap pembelajaran daring PJOK sebaran skornya semakin dekat dari skor rata-ratanya, yang mengindikasikan skor persepsi peserta didik terhadap pembelajaran daring PJOK tidak jauh berbeda (tidak bervariasi). Berdasarkan hasil analisis skor persepsi peserta didik terhadap pembelajaran daring PJOK pada kelas VIII di SMP Negeri 1 Singaraja, maka dapat disajikan distribusi frekuensi seperti pada Tabel 2 .

Tabel 2. Distribusi Frekuensi Data Skor Persepsi Peserta Didik Terhadap Pembelajaran Daring PJOK

\begin{tabular}{|c|c|c|c|}
\hline Kelas Interval & Kategori & Frekuensi & Persentase \\
\hline $104 \leq \mathrm{M} \leq 130$ & Sangat baik & 29 & $15,76 \%$ \\
\hline $86,67 \leq M<104$ & Baik & 77 & $41,85 \%$ \\
\hline $69,33 \leq M<86,67$ & Cukup & 64 & $34,78 \%$ \\
\hline $52 \leq \mathrm{M}<69,33$ & Kurang & 14 & $7,61 \%$ \\
\hline $26 \leq M<52$ & Sangat kurang & 0 & $0,00 \%$ \\
\hline \multicolumn{2}{|c|}{ Jumlah } & 184 & $100,00 \%$ \\
\hline
\end{tabular}

Berdasarkan Tabel 2, skor persepsi peserta didik terhadap pembelajaran daring PJOK pada kelas VIII di SMP Negeri 1 Singaraja berada pada kategori sangat baik sebanyak 29 peserta didik $(15,76 \%)$, berada pada kategori baik sebanyak 77 peserta didik (41,85\%), berada pada kategori cukup sebanyak 64 peserta didik (34,78\%), berada pada kategori kurang sebanyak 14 peserta didik $(7,61 \%)$, dan tidak ada peserta didik yang memiliki skor persepsi sangat kurang (0,00\%). Adapun skor rata-rata persepsi peserta didik terhadap pembelajaran daring PJOK sebesar 89,91 berada pada rentang kategori 86,67 $\leq \mathrm{M}<104$, sehingga skor rata-rata persepsi peserta didik terhadap pembelajaran daring PJOK memiliki kategori baik. Data tersebut menunjukkan bahwa sebagan besar peserta didik memiliki persepsi yang baik terhadap pembelajaran daring PJOK. Persepsi peserta didik yang baik terhadap pembelajaran daring menunjukkan bahwa peserta didik mampu mengikuti proses pembelajaran daring dengan baik. Siswa mampu memahami materi yang diberikan oleh guru walaupun tidak belajar secara tatap muka. Hal ini juga menunjukkan bahwa minat serta motivasi belajar peserta didik tinggi untuk mengikuti proses pembelajaran. Keberhasilan pembelajaran daring tentu tidak dapat dilepasakan dari peran guru, orang tua siswa, serta media yang digunakan guru dalam mengajar. Pembelajaran yang dilakukan oleh pendidik selama pandemi harus memliki inovasi baru dan lebih menarik sehingga dapat membantu mempermudah 
peserta didik dalam menjalani pembelajaran daring (Anugrahana, 2020; Sutini et al., 2020). Media online atau e-learning saat melakukan pembelajaran daring sangat efektif namun terdapat beberapa hal yang harus diperbaiki oleh pendidik untuk memaksimalkan pembelajaran, misalnya dalam pemberian materi dan pemberian tugas pendidik harus lebih mempertimbangkan hal-hal yang dapat terjadi (Mustakim, 2020). Persepsi baik peserta didik terhadap pembelajaran daring karena peserta didik merasakan bahwa pembelajaran daring lebih santai, menyenangkan, fleksibel, efisien, singkat, praktis, cepat, tepat, aman, mudah, hemat waktu, dan hemat tenaga (Jamilah, 2020).

Hal tersebut da[at terlihat dari hasil analisis data pada persepsi peserta didik terhadap pembelajaran daring PJOK pada kelas VIII di SMP Negeri 1 Singaraja berada pada kategori sangat baik sebanyak 29 peserta didik (15,76\%), berada pada kategori baik sebanyak 77 peserta didik (41,85\%), berada pada kategori cukup sebanyak 64 peserta didik (34,78\%), dan berada pada kategori kurang sebanyak 14 peserta didik (7,61\%). Hal ini dapat sejalan dengan penelitian (Sari \& Nazirun, 2016) yang menyatakan bahwa siswa mempunyai persepsi yang baik terhadap proses pembelajaran pendidikan jasmani olahraga dan kesehatan itu sendiri. Maka dapat disimpulkan bahwa persepsi siswa terhadap proses pembelajaran pendidikan jasmani olahraga dan kesehatan adalah masuk kedalam kategori baik. Senada dengan itu, hasil yang sama juga ditunjukkan oleh penelitian (Fandra \& Umari, 2019) yang menyatakan bahwa persepsi siswa terhadap proses pembelajaran pendidikan jasmani olahraga dan kesehatan adalah masuk kedalam kategori baik. Penelitian yang dilakukan oleh (Zuriati \& Briando, 2020) menunjukkan bahwa dalam pelaksanaan pembelajaran daring terdapat beberapa dimensi yang harus menjadi perhatian utama. Dimensi tersebut antara lain: Materi atau mode ajar, interaksi siswa, dan suasana belajar. Oleh karena itu, penelitian ini memiliki fokus pada persepsi siswa terhadap dimensi pelaksanaan pembelajaran daring. Jadi persepsi peserta didik dalam mengikuti pembelajaran PJOK berbasis daring sudah tergolong baik.

\section{SIMPULAN DAN SARAN}

Berdasarkan penjelasan yang sudah di paparkan di atas dapat di simpulkan bahwa persepsi peserta didik terhadap pembelajaran daring PJOK pada kelas VIII di SMP Negeri 1 Singaraja tergolong baik. Peserta didik kelas VIII di SMP Negeri 1 Singaraja memiliki persepsi yang baik terhadap pembelajaran daring PJOK. Hal tersebut ditunjukkan dengan skor rata-rata persepsi peserta didik terhadap pembelajaran daring PJOK sebesar 89,91 berada pada kategori baik. Sehingga guru PJOK ke depan agar kreatif dan inovatif dalam menyajikan materi ajar, interaksi peserta didik, dan suasana belajar. Hal ini diharapkan menjadi fokus utama kepada guru agar persepsi siswa terhadap pelaksanaan pembelajaran daring semakin baik, sehingga peserta didik menerima dan bersemangat menjalani proses pembelajaran di masa-masa pandemi ini. Sekolah ke depan diharapkan ikut berperan aktif untuk meningkatkan memfasilitasi pembelajaran berbasis daring pada peserta didik dengan memperhatikan faktor-faktor pendukung proses pembelajaran.

\section{DAFTAR RUJUKAN}

Adila, K., \& Harisah, Y. (2020). Persepsi Siswa Kelas X MIPA SMA Negeri 1 Bojong Terhadap Pembelajaran Online pada Pelajaran Mate matika. Seminar Nasional Pendidikan Matematika, 1(1), 401-406. Retrieved from. https://proceeding.unikal.ac.id/index.php/sandika/article/download/433/359/.

Anugrahana, A. (2020). Hambatan, Solusi dan Harapan: Pembelajaran Daring Selama Masa Pandemi Covid-19 Oleh Guru Sekolah Dasar. Scholaria: Jurnal Pendidikan Dan Kebudayaan, 10(3), 282-289. https://doi.org/10.24246/j.js.2020.v10.i3.p282-289.

Anwar, J. F., \& Hartoto, S. (2019). Hubungan Aktivitas Fisik Di Luar Jam Pelajaran PJOK dengan Tingkat Kebugaran Jasmani. Jurnal Pendidikan Olahraga Dan Kesehatan, 7(3), 43-47.

Buana, D. R. (2020). Analisis Perilaku Masyarakat Indonesia dalam Menghadapi Pandemi Virus Corona (Covid-19) dan Kiat Menjaga Kesejahteraan Jiwa. Salam: Jurnal Sosial Dan Budaya Syar-I, 217226.

Fandra, \& Umari, A. (2019). Persepsi Siswa Terhadap Proses Pembelajaran Pendidikan Jasmani Olahraga dan Kesehatan di SMP Negeri 2 Batipuh. Jurnal Pendidikan Dan Olahraga, 2(4), 2 2-2 9. Retrieved from. http://jpdo.ppj.unp.ac.id/index.php/jpdo/article/view/595.

Firman, F., \& Rahayu, S. (2020). Pembelajaran Online di Tengah Pandemi Covid-19. Indonesian Journal of Educational Science (IJES), 2(2), 81-89. https://doi.org/10.31605/ijes.v2i2.659

Hadi, L. (2020). Persepsi Mahasiswa Terhadap Pembelajaran Daring Di Masa Pandemik Covid-19 Student Perceptions of Online Learning During Covid-19 Pandemic. Jurnal Zarah, 8(2), 56-61.

Hendri, G., \& Azis, I. (2020). Motivasi siswa dalam proses pembelajaran pendidikan jasmani olahraga 
kesehatan. Jurnal Patriot, 2(1), 171-181.

Henik, I, Indarto A.S, D. T. (2014). (2014) 'Persepsi Mahasiswa Tentang Media Pembelajaran E- Learning', ,. Jurnal Ilmu Kebidanan, 2(2).

Imania, K. A., \& Bariah, S. K. (2019). Rancangan Pengembangan Instrumen Penilaian Pembelajaran Berbasis Daring. Jurnal Pendidikan Teknologi Informasi Dan Komunikasi (PETIK), 5(1), 31-47.

Irawati, R., \& Santaria, R. (2020). Persepsi Siswa SMAN 1 Palopo Terhadap Pelaksanaan Pembelajaran Daring Mata Pelajaran Kimia. Jurnal Studi Guru Dan Pembelajaran, 3(2), 264-270. https://doi.org/10.30605/jsgp.3.2.2020.286.

Jamilah. (2020). Guru profesional di era new normal: Review peluang dan tantangan dalam pembelajaran daring. Premiere Educandum: Jurnal Pendidikan Dasar Dan Pembelajaran, 10(2), 238-247. https://doi.org/10.25273/pe.v10i2.7494.

Jariyah, I. A., \& Tyastirin, E. (2020). Proses dan Kendala Pembelajaran Biologi di Masa Pandemi Covid-19: Analisis Respon Mahasiswa. Jurnal Penelitian Dan Pengkajian Ilmu Pendidikan:E-Saintika, 4(2), 183-196. https://doi.org/10.36312/e-saintika.v4i2.224.

Juniarta, A. T., \& Winarno, M. . (2016). Pengembangan Instrumen Penilaian Pengetahuan Mata Pelajaran Pendidikan. Jurnal Pendidikan, 1(7), 1449-1463.

Margiyanti, N. J., Handayani, T. Y., \& Roza, N. (2021). Pengaruh Pembelajaran Berbasis Daring Terhadap Prestasi Mahasiswa Prodi Diploma Iii Kebidanan. Jurnal Visi Ilmu Pendidikan, 13(2), 132-137. https://doi.org/10.26418/jvip.v13i2.46448.

Maulana, H. A., \& Iswari, R. D. (2020). Analisis Tingkat Stres Mahasiswa Terhadap Pembelajaran Daring Pada Mata Kuliah Statistik Bisnis Di Pendidikan Vokasi. Jurnal Ilmiah Kependidikan, 14(1), 17-30. https://doi.org/10.30595/jkp.v14i1.8479.

Mustakim. (2020). Efektivitas Pembelajaran Daring Menggunakan Media Online Selama Pandemi Covid-19 Pada MataPelajaran Matematika. Al Asma: Journal of Islamic Education, 2(1), 1-12.

Mustofa, M. I., Chodzirin, M., \& Sayekti, L. (2019). Formulasi Model Perkuliahan Daring Sebagai Upaya Menekan Disparitas Kualitas Perguruan Tinggi. Walisongo Journal of Information Technology, 1(2), 151-160.

Napitupulu, R. M. (2020). Dampak pandemi Covid-19 terhadap kepuasan pembelajaran jarak jauh. Jurnal Inovasi Teknologi Pendidikan, 7(1), 23-33. https://doi.org/10.21831/jitp.v7i1.32771.

Ni'mah. (2016). Manajemen Pembelajaran Jarak Jauh (Distance Learning) pada Homeschooling"Sekolah Dolan"'. Manajemen Pendidikan, 25(1), 112- 119.

Pakpahan, R., \& Fitriani, Y. (2020). Analisa Pemafaatan Teknologi Informasi Dalam Pemeblajaran Jarak Jauh Di Tengah Pandemi Virus Corona Covid-19. JISAMAR (Journal of Information System, Applied, Management, Accounting and Researh), 4(2), 30-36.

Pertiwi, R. K., \& Sutama. (2020). Membudayakan Kelas Digital Untuk Membimbing Siswa Dalam Pembelajaran Di Tengah Pandemi Covid-19. JKTP Jurnal Kajian Teknologi Pendidikan, 3(4), 350365. https://doi.org/10.17977/um038v3i42020p350.

Prayitno, \& Mardianto, M. F. F. (2020). Peningkatan Hasil Evaluasi Pembelajaran Daring Saat Pandemi Covid-19 Berdasarkan Media Powerpoint Interaktif. MUST: Journal of Mathematics Education, Science and Technology, 5(2), 171-181. https://doi.org/10.30651/must.v5i2.6119.

Putri, A., \& Suparmi. (2020). Putri, A. N., Pd, M. E. and Pd, M. E. (2020) 'Efektivitas Pembelajaran Daring Program Studi Pendidikan Ekonomi.' Jurnal Ecogen, 3(4), 627-634. https://doi.org/10.24036/jmpe.v3i4.10618.

Putri, R. S., \& Purwanto, D. (2020). (2020). Impact of the COVID-19 pandemic on online home learning: An explorative study of primary schools in Indonesia. International ,. Journal of Advanced Science and Technology, 29(5), 4809-4818.

Rahman, I., Gani, R. A., \& Achmad, I. Z. (2020). Persepsi Siswa Pada Pembelajaran Pendidikan Jasmani Olahraga Dan Kesehatan Tingkat Sma. Jurnal Pendidikan Olahraga, 9(2), 144-154. https://doi.org/10.31571/jpo.v9i2.1898.

Rochman, B., Indahwati, N., \& Priambodo, A. (2020). Identifikasi Keterlaksanaan Pembelajaran PJOK Tingkat SMP Di Masa Pandemi Covid 19 Se-Kabupaten Sidoarjo. Jurnal Ilmiah Mandala Education, 6(1), 257-265. https://doi.org/10.36312/jime.v6i1.1343.

Sari, M., \& Nazirun, N. (2016). Persepsi Siswa Kelas Viii Terhadap Proses Pembelajaran Pendidikan Jasmani Olahraga Dan Kesehatan Di Smp Negeri 5 Pekanbaru. Journal of Chemical Information and Modeling, 1(269-277), 269-277.

Susilo, A., Rumende, C. M., Pitoyo, C. W., Santoso, W. D., Yulianti, M., Herikurniawan, H., ... Yunihastuti, E. (2020). Coronavirus Disease 2019: Tinjauan Literatur Terkini. Jurnal Penyakit Dalam Indonesia, 7(1), 45. https://doi.org/10.7454/jpdi.v7i1.415.

Sutini, Mushofan, M., Ilmia, A., Yanti, A. D., Rizky, A. N., \& Lailiyah, S. (2020). Efektivitas Pembelajaran 
Daring Dengan Menggunakan E-Learning Madrasah Terhadap Optimalisasi Pemahaman Matematika Siswa. JRPM (Jurnal Review Pembelajaran Matematika), 5(2), 124-136. https://doi.org/10.15642/jrpm.2020.5.2.124-136.

Wilder-Smith, A., \& Freedman, D. O. (2020). Isolation, quarantine, social distancing and community containment: Pivotal role for old-style public health measures in the novel coronavirus (2019nCoV) outbreak. ,. Journal of Travel Medicine, 27(2), 1-4. https://doi.org/10.1093/jtm/taaa020.

Zuriati, S., \& Briando, B. (2020). Webinar dan Call for Papers “ Menyongsong Era Merdeka Belajar ” 2020. Menyongsong Era Merdeka Belajar, (June), 1-14. 